\title{
Caustic Esophageal Stenosis: Epidemiological, Clinical, Endoscopic and Therapeutic Aspects at the Gabriel Touré University Hospital in Bamako
}

\author{
Sow Hourouma wife Coulibaly*, Doumbia Kadiatou wife Samaké, Dicko Moussa Younoussa, \\ Tounkara Makan Siré, Sanaogo Déborah wife Sidibé, Anselme Konaté, \\ Moussa Tiemoko Diarra, Moussa Youssoufa Maiga
}

Department of Hepato-Gastroenterology, Gabriel Touré University Hospital Center, Bamako, Mali

Email: *sowhourouma@yahoo.fr

How to cite this paper: Coulibaly, S.H.W., Samaké, D.K.W., Younoussa, D.M., Siré, T.M., Sidibé, S.D.W., Konaté, A., Diarra, M.T. and Maiga, M.Y. (2021) Caustic Esophageal Stenosis: Epidemiological, Clinical, Endoscopic and Therapeutic Aspects at the Gabriel Touré University Hospital in Bamako. Open Journal of Gastroenterology, 11, 203209.

https://doi.org/10.4236/ojgas.2021.1110021

Received: April 27, 2021

Accepted: October 26, 2021

Published: October 29, 2021

Copyright $\odot 2021$ by author(s) and Scientific Research Publishing Inc. This work is licensed under the Creative Commons Attribution International License (CC BY 4.0).

http://creativecommons.org/licenses/by/4.0/ (c) (i) Open Access

\begin{abstract}
Voluntary or accidental ingestion of a caustic product is increasingly encountered in our country. Caustic esophageal stenosis is the most common sequel. Its treatment involves instrumental dilation and/or surgery which is particularly heavy. The aim of this study was to study the epidemiological, clinical and therapeutic aspects of caustic esophageal strictures in our context. The retrospective study took place from December 2013 to December 2017 in the Hepato-Gastroenterology department of the Gabriel Touré university hospital in Bamako. We included patients with caustic esophageal stenosis referred to the gastrointestinal endoscopy unit for dilation. 67 patients admitted for caustic stenosis were included. The mean age of our patients was $20.76 \pm 19.9$ years with extremes of 1 and 70 years and a sex ratio of 1.9 . In $50.7 \%$ of cases, the product ingested was basic in nature. The clinical symptomatology was dominated by dysphagia (100\%), vomiting (100\%), the emaciated (60\%) and cough $(40 \%)$. In $59(88 \%)$ patients, the stenosis was unique and multiple in 8 (12\%). The KILLIAN mouth as the sole site of the stenosis was found in $40.3 \%$ of patients. The number of sessions was $\leq 3$ in $16.4 \%$ and $>3$ in $83.6 \%$ with a mean of $4.59 \pm 1.57$ sessions. The evolution was favorable in $95.5 \%$ of our patients. However, we recorded three (3) cases of death all following a perforation. Conclusion: Caustic esophageal stenosis, a consequence of ingestion of caustics, is increasingly observed in our context. Endoscopic dilation occupies an important place in its management.
\end{abstract}

\section{Keywords}

Causticstenosis, Esophagus, Endoscopic Dilatation 


\section{Introduction}

The voluntary or accidental ingestion of caustic is increasingly encountered in our country and is a real public health problem today. The resulting complications can be serious and deadly, involving the vital prognosis or causing disabling sequelae. Caustic esophageal stenosis (SCO), the most frequent sequel to these burns, can be severe, leading to dysphagia or even aphagia with a deficit in weight and a significant deterioration in the patient's quality of life [1]. Its treatment involves instrumental dilation and/or surgery, which is particularly heavy [2] [3]. The incidence of caustic accidents varies from region to region. While this incidence is clearly decreasing in developed countries thanks to legislation and information campaigns carried out among parents and industry. However, it remains high in developing countries in the absence of adequate measures. In Africa, Oumnia et al. collected 132 cases of caustic esophageal stenosis in four years [1] while Yéna et al. collected 67 cases in seven years [4]. Formerly mainly surgical, the treatment of caustic esophageal stenosis has become accessible to endoscopic dilation as a first-line. Surgery now seems to be reserved for dilation failures and can even, in some cases, be coupled to it [5]. Caustic burns are relatively frequent in our department and their management is difficult because of the insufficient technical platform and the delay in the consultation. We initiated this work with the aim of studying its epidemiological, clinical and therapeutic aspects.

\section{Patients and Method}

This was a retrospective study extending from December 2013 to December 2017 in the hepato-gastroenterology department of the Gabriel Touré university hospital in Bamako/Mali. Our inclusion criteria were:

- Patients with esophageal stricture after ingestion of caustic products;

- Caustic stenosis having benefited from endoscopic dilation sessions.

Non-caustic esophageal strictures were excluded. For the development of this work we used the department registers, patient records and the reports of gastrointestinal endoscopy accounts.

We studied:

- The demographic data (age, sex, occupation);

- The nature of the caustic product, the clinical manifestations;

- The morphological lesions endoscopic and radiological (transit œesogastroduodénal);

- The therapeutic techniques (instrumental expansion and/or surgery) and evolution.

For the endoscopic dilation, we used a metal guide wire fitted at its end with a very flexible tip or a hydrophilic guide wire, a set of candles semi-transparent GUILLARD (diameter from 5 to $18 \mathrm{~mm}$ ) and/or a pneumatic dilator (through the scope TTS balloon). 
All dilation sessions were performed on an outpatient basis, without general anesthesia. The fasting patients on the day of dilation received as premedication an intravenous injection of $10 \mathrm{mg}$ of diluted diazepam, $5 \%$ glucose serum and 5 $\mathrm{mm}$ before the session pharyngeal anesthesia was performed with $2 \%$ viscous lidocaine. After premedication, the patient is placed in a left lateral decubitus position. First, an upper gastrointestinal endoscopy is performed with an adult or pediatric video endoscope (most often). The fiberscope is introduced to the level of the upper opening of the stenosis. The guidewire is introduced into the working canal, and then carefully pushed under visual control, through the stenosis, into the stomach, for a length of at least $30 \mathrm{~cm}$. The fiberscope is then withdrawn slowly while holding the guidewire in place. The successive dilation is then carried out taking into account the diameter of the stenosis, with the candles of increasing caliber threaded on the guidewire without exceeding 03 candles per session. The passage of the candle through the stenotic segment is marked by a sensation of jumping preceded by resistance, usually moderate. But faced with any abnormally strong resistance and if the stenosis is complex in the oeso-gastroduodenal transit, the pneumatic dilator is first used under visual control and in parallel with the pediatric endoscope before the candles of SAVARY GUILLARD. After each dilation, an endoscopic check is made to assess the mucosa. Once the last candle has passed, the guidewire is completely removed after endoscopic control. The patient is then put placed on a Proton Pump Inhibitor (PPI) and paracetamol in case of pain, and allowed to eat 3 hours after the session for children and 6 hours for adults.

Data entry and data analysis were performed on SPSS 12.0 software for Windows. We simply entered texts and tables on the World and Excel software. The confidentiality of the data collected was guaranteed. The Chi-square statistical test was used to compare our results which were significant for a probability $\mathrm{p}<$ 0.05 .

\section{Results}

In this study 67 patients admitted for caustic stenosis were included. On the socio-demographic level (Table 1): the mean age of the patients was $20.76 \pm 19.9$ years with extremes of 1 and 70 years and a sex ratio of 1.9. In $49.3 \%$ our patients had no professional activity. In $50.7 \%$ of cases, the product ingested was a base and in $49.3 \%$ an acid. The clinical symptomatology was dominated by dysphagia (100\%), vomiting (100\%), the emaciated and cough (40\%). In $88 \%$ of patients the stenosis was single and multiple in $12 \%$ (six cases of double stenosis and six cases of triple stenosis) (Table 2). For single stenosis, Killian's mouth was the site in $40.3 \%$ of cases, the middle $1 / 3$ of the esophagus in $10.4 \%$, and the lower $1 / 3$ in $34.3 \%$. For double stenosis, $3 \%$ were located at the level of the middle $1 / 3$ and lower $1 / 3,7.5 \%$ at the level of Killian's mouth and of the middle $1 / 3$ and $4.5 \%$ at the level of the mouth of Killian and the lower $1 / 3$ of the esophagus. (Table 3). The number of sessions was $\leq 3$ in $16.4 \%$ and $>3$ in $83.6 \%$ with an 
Table 1. Sociodemographic data.

\begin{tabular}{lcc}
\hline \multicolumn{1}{l}{ Sociodemographic data } & Numbers $\mathbf{n}=67$ & $\%$ \\
\hline Sex & 44 & 65.7 \\
Male & 23 & 34.3 \\
Female & & \\
Age in years & 33 & 49.3 \\
1 - 20 & 23 & 34.3 \\
21 - 40 & 9 & 13.4 \\
$41-60$ & 2 & 3 \\
61 - 80 & & \\
Profession & 11 & 16.4 \\
Housewife & 5 & 7.5 \\
Cultivator & 7 & 10.4 \\
Trader & 3 & 4.5 \\
Student & 2 & 3 \\
Civil servant & 6 & 8.9 \\
Worker & 33 & 49.3 \\
No occupation & & \\
\hline
\end{tabular}

Table 2. Distribution of patients according to the number of stenosis.

\begin{tabular}{ccc}
\hline Number of stenosis & Numbers & $\%$ \\
\hline Single & 59 & 88 \\
Double & 4 & 6 \\
Triple & 4 & 6 \\
Total & 67 & 100 \\
\hline
\end{tabular}

Table 3. Distribution of patients according to the topography of the lesions.

\begin{tabular}{lcc}
\hline \multicolumn{1}{c}{ Topography of lesions } & Numbers & $\%$ \\
\hline Stenosis of the mouth of Killian & 27 & 40.3 \\
1/3 middle esophagus & 7 & 10.4 \\
1/3 middle and lower esophagus & 2 & 3 \\
Killian's mouth stenosis + middle 1/3 esophagus & 5 & 7.5 \\
Stenosis of Killian's mouth and lower 1/3 of the esophagus & 3 & 4.5 \\
1/3 lower esophagus & 23 & 34.3 \\
Total & 67 & 100 \\
\hline
\end{tabular}

average of $4.59 \pm 1.57$ sessions (Table 4). The interval between dilation sessions was 4 weeks. The outcome was often favorable after dilation in $95.5 \%$ of our patients. Complications accounted for $4.5 \%$ of the type of perforation leading to the death of these patients after their transfer to surgery. We found a statistically significant relationship between the number of dilation sessions and the course of the disease (Table 5). 
Table 4. Distribution of patients according to the number of dilation sessions.

\begin{tabular}{ccc}
\hline Number of session & Numbers & $\%$ \\
\hline 1 & 4 & 6 \\
2 & 1 & 1.5 \\
3 & 6 & 8.9 \\
4 & 31 & 46.3 \\
5 & 6 & 8.9 \\
6 & 13 & 19.4 \\
7 & 1 & 1.5 \\
8 & 5 & 7.5 \\
Total & 67 & 100 \\
\hline
\end{tabular}

Table 5. Distribution of patients according to the evolution and the number of dilation sessions.

\begin{tabular}{ccccc}
\hline \multirow{2}{*}{ Evolution } & \multicolumn{2}{c}{ Favorable } & \multicolumn{2}{c}{ Deceased } \\
\cline { 2 - 5 } Number of session & Number & $\%$ & Number & $\%$ \\
\hline 1 & 1 & 1.6 & 2 & 66.7 \\
2 & 1 & 1.6 & 0 & 0 \\
3 & 6 & 9.3 & 0 & 0 \\
4 & 30 & 46.9 & 1 & 33.3 \\
5 & 6 & 9.3 & 0 & 0 \\
6 & 14 & 21.9 & 0 & 0 \\
7 & 1 & 1.6 & 0 & 0 \\
8 & 5 & 7.8 & 0 & 0 \\
Total & 64 & 100 & 3 & 100 \\
\hline
\end{tabular}

$\mathrm{Khi}^{2}=21.34 ; \mathrm{p}=0.0032 ; \mathrm{ddl}=7$.

\section{Discussion}

We collected 67 patients who underwent endoscopic dilation. Our sample was limited by the difficulties in achieving dilation in some patients for financial reasons. The sex-ratio was 1.9. This male predominance has also been reported by Rakesh et al. [6] and Togo et al. [7]. The mean age of our patients was $20.76 \pm$ 19.9 years. Rheman et al. [8] found in their study an average age of 19.25 years while Rakesh et al. [6] found an average age of 35.5 years. Although this incident affects all age groups, it occurs more frequently in adolescents and young adults. This is often an impulsive act, as this period is characterized by the onset of psycho-affective disorders in a context of emotional immaturity or isolation, which may explain this high percentage. In our study, in $50.7 \%$ of cases the product ingested was a baseline against $85.1 \%$ in that of Sanchez et al. [9] and $89.2 \%$ in the series of Rakesh et al. [6]. It has been reported that alkaline substances account for most cases of caustic ingestion in developed countries while acid ingestion is more common in developing ones [10]. The clinical symptomatology 
was dominated by dysphagia (100\%), vomiting (100\%), the emaciated and cough (40\%). Ahmed et al. [11] reported 76.7\% dysphagia, $69.8 \%$ vomiting and $4.2 \%$ epigastric pain. In 59 patients (88\%) the stenosis was unique and multiple in 8 patients (12\%). The strictures were preferentially located at the level of the Killian mouth and in the lower $1 / 3$ of the esophagus. Mekki et al. [12] demonstrated the stricture at the upper $1 / 3$ level in $40 \%$ of patients, $2 / 3$ higher in $40 \%, 1 / 3$ mean in $10 \%$ and $1 / 3$ lower in $10 \%$. The number of sessions was $\leq 3$ in $16.4 \%$ and $>3$ in $83.6 \%$ with an average of $4.59 \pm 1.57$. Youn et al. [13] and Ahmed et al. [11] respectively reported an average number of sessions of 4 and 3 . The evolution was favorable with resumption of feeding in $95.5 \%$ of our patients. Our success rate is higher than that of Geng et al. [14] who found a favorable outcome in $60.5 \%$ of cases and significantly higher than that of Tadmori et al. [15] who found $30 \%$ success. Three cases of perforation complicated the procedure.

\section{Conclusion}

Caustic esophageal stenosis is the main long-term complication of caustic ingestion. It is more and more common in our country. Endoscopic dilation is a simple, effective and accessible therapeutic means in our context. However, prevention remains the best treatment for caustic burns.

\section{Conflicts of Interest}

The authors declare no conflicts of interest regarding the publication of this paper.

\section{References}

[1] Oumnia, N., Lahcene, M., Tebaibia, N., Matougui, N., Boudjella, M.L. and Touchene, B. (2010) Traitement par dilatation instrumentale des sténoses caustiques de l'œsophage de l'adulte: Étude prospective de 132 cas. Journal Africain d Hépato-Gastroentérologie, 4, 205-209. https://doi.org/10.1007/s12157-010-0209-3

[2] Ganga-Zandzou, P.S., Devulder, C. and Michaud, L. (1998) Long Term Follow-Up of Children with Esophageal Caustic Stenosis. Archives de Pédiatrie, 6, 610-616. https://doi.org/10.1016/S0929-693X(98)80162-0

[3] De La Rionda, L.M., Fragos, T., Sagero, E., et al. (1995) Treatment with Savary-Gilliard Bougies in Esophageal Stenosis in Children. Revista de Gastroenterología del Perú, 15, 152-157.

[4] Yéna, S., Togo, S., Ouattara, M.A., Sankaré, I., Tu, Z.L., Maïga, I.B., et al. (2015) Les sténoses caustiques de l'œsophage de l'enfant en chirurgie. Quelle stratégie thérapeutique pour un pays en développement? Journal de Chirurgie thoracique et cardio-vasculaire, 19, 149-154.

[5] Ferraro, F., Turck, D., Gottrand, F., Rigaut, J.F., Valle, M.B., et al. (1996) Dilatation de l'œsophage par les bougies de SAVARY: Expérience chez 34 enfants. Annales de pédiatrie, 42, 552-561.

[6] Rakesh, K., Sarthak, M., Yalaka, R.R., Bipadabhanjan, M., Narendra, D., Pankaj, G., et al. (2019) Endoscopic Balloon Dilatation Is an Effective Management Strategy for Caustic-Induced Gastric Outlet Obstruction: A 15-Year Single Center Experience. 
Endoscopy International Open, 7, E53-E61. https://doi.org/10.1055/a-0655-2057

[7] Togo, S., Ouattara, M.A., Xing, L., Sanogo, Z.Z., Koumaré, S., Wen, Y.S., et al. (2016) Apport des moyens endoscopiques dans la dilatation des sténoses caustiques de l'œsophage. The Pan African Medical Journal, 23, 24. https://doi.org/10.11604/pamj.2016.23.24.8506

[8] Rhman, S., Hameed, K. and Khan, I.M. (2007) Endoscopic Dilatation for Caustic Esophageal Stricture. Journal of Postgraduate Medical Institute, 21, 292-295.

[9] Sanchez, R.C.A., Larrosa, H.A., Vaquez-Garibay, E.M. and Macias-Rosales, R. (2012) Socio-Demographic Factors Associated with Caustic Substance Ingestion in Children and Adolescents. International Journal of Pediatric Otorhinolaryngology, 76, 253-256. https://doi.org/10.1016/j.ijporl.2011.11.015

[10] Sabzevari, A., Maamouri, G., Kiani, M.A., Saeidi, M., Kianifar, H., Jafari, S.A., et al. (2017) Clinical and Endoscopic Findings of Children Hospitalized in Qa'em Hospital of Mashhad Due to Caustic Ingestion (2011-2013). Electronic Physician, 4, 4248-4250. https://doi.org/10.19082/4248

[11] Ahmed, A.A.S., Anjum, S., Yassin, H.H., Mona, M.A.A., Tariq, I.A., Anhar, A.U., et al. (2018) Efficacy and Safety of Endoscopic Dilatation in the Management of Esophageal Strictures in Children. Saudi Medical Journal, 39, 787-791.

https://doi.org/10.15537/smj.2018.8.22845

[12] Mekki, M., Said, M., Belghith, M., Krichène, I., Chelly, S., Jouini, R., et al. (2001) Dilatation pneumatique des sténoses caustiques de l'œsophage. A propos de cinq cas. Archives de Pédiatrie, 8, 489-492. https://doi.org/10.1016/S0929-693X(00)00250-5

[13] Youn, B.J., Kim, W.S., Cheon, J.-E., Kim, W.-Y., Shin, S.-M., Kim, I.-O., et al. (2010) Balloon Dilatation for Corrosive Esophageal Strictures in Children: Radiologic and Clinical Outcomes. Korean Journal of Radiology, 11, 203-210. https://doi.org/10.3348/kjr.2010.11.2.203

[14] Geng, L.-L., Liang, C.-P., Chen, P.-Y., Wu, Q., Yang, M. and Li, H.-W. (2018) LongTerm Outcomes of Caustic Esophageal Stricture with Endoscopic Balloon Dilatation in Chinese Children. Gastroenterology Research and Practice, 2018, Article ID: 8352756. https://doi.org/10.1155/2018/8352756

[15] Tadmori, I. (2015) Hide MDifficulté de prise en charge de la sténose caustique de l'oesophage chez l'enfant (série de 10 cas). Journal de Pédiatrie et de Puericulture, 28, 177-184. https://doi.org/10.1016/j.jpp.2015.05.005 